\title{
CARA INDONESIA MENANGGULANGI CORONA VIRUS DISEASE-19 MELALUI PERATURAN PERUNDANG-UNDANGAN
}

\author{
HOW INDONESIA AGAINST CORONA VIRUS DISEASE 2019 \\ WITH LAWS AND REGULATIONS
}

\author{
M. Zamroni ${ }^{1}$ \\ 1. Program Studi Ilmu Hukum, Fakultas Hukum, Universitas Maarif Hasyim Latif \\ Jalan Ngelom Megare 30, Taman, Sidoarjo, Jawa Timur, 61257. \\ Email: zamroni@dosen.umaha.ac.id.
}

\begin{abstract}
Indonesia has had Act Number 6 Year 2018 on Health Quarantine, since it was invited on August 8, 2018, this law became the first stepping up the legislation in Indonesia to deal with Covid-19, then later the statutory regulations what is stipulated in Indonesia to deal with the Covid-19 outbreak?, and how effective are these regulations on countering the Covid-19 outbreak?. This research is expected to be able to explore how the Indonesian state cope with Covid-19 with legislative products, and from the products of the legislation it can be analyzed the effectiveness of the Indonesian state's resolution of the Covid19 outbreak. This research uses qualitative research methodology, as well as normative legal research methods, which focus on statutory regulations, with a legislative approach and several cases that occur. This research is expected to answer the effectiveness of laws and regulations on handling of Covid-19 in Indonesia, that the product of the legislation turned out to be able to participate in a significant response to the Covid-19 outbreak, which is to slow the development of the Covid-19 outbreak, although it cannot completely eliminate this outbreak.
\end{abstract}

Keywords: Quarantine, social restrictions, covid -19

\section{Intisari}

Indonesia telah memiliki Undang-Undang Nomor 6 Tahun 2018 tentang Kekarantinaan Kesehatan, sejak diundangkan pada tanggal 8 Agustus 2018 undang-undang ini menjadi pijakan pertama peraturan perundang-undangan di Indonesia untuk menanggulangi Covid-19, lalu kemudian peraturan perundangundangan apa saja yang ditetapkan di Indonesia untuk menanggulangi wabah Covid-19?, serta bagaimana efektifitas peraturan-peraturan tersebut terhadap penanggulangan wabah Covid-19?. Penelitian ini diharapkan dapat menelusuri cara negara Indonesia menanggulangi Covid-19 dengan produk perundangundangan, serta dari produk perundang-perundang itu dapat dianalisa efektifitas penyelesaian negara Indonesia terhadap wabah Covid-19. Penelitian ini menggunakan metodologi penelitian kualitatif, serta metode penelitian hukum yuridis normatif, yang fokus pada peraturan perundang-undangan, dengan pendekatan perundang-undangan dan beberapa kasus yang terjadi. Penelitian ini diharapkan dapat menjawab efektifitas peraturan perundang-undangan terhadap 
penanggulangan Covid-19 di Indonesia, bahwa produk peraturan perundangundangan ternyata bisa ikut serta menanggulangi wabah Covid-19 secara cukup sifnifikan, yakni memperlambat perkembangan wabah Covid-19, walaupun tidak bisa menghilangkan wabah ini secara tuntas.

Kata Kunci: Karantina, pembatasan sosial, covid-19

\section{- $\quad$ Latar Belakang Masalah}

Istilah Coronavirus Disease 2019 (Covid-19) dipakai oleh World Health Organization (WHO) untuk menyebut penyakit menular yang disebabkan oleh jenis Coronavirus yang baru ditemukan. Ini merupakan penyakit yang tidak dikenal sebelum terjadi wabah di Wuhan, ibu kota Provinsi Hubei, Republik Rakyat Tiongkok, pada bulan Desember 2019, yang memiliki penduduk berjumlah 9.100.000 jiwa. ${ }^{1}$ Setelah melalui identifikasi dan isolasi virus, patogen untuk pneumonia ini awalnya disebut 2019 novel coronavirus (2019-nCoV) 2 tetapi kemudian secara resmi dinamai sindrom pernapasan akut parah coronavirus 2 (SARS-CoV-2) oleh WHO. ${ }^{2}$

Kemudian Covid-19 ini menyebar ke beberapa negara, akhirnya pada tanggal 11 Maret 2020, WHO menetapkan Covid-19 sebagai Pandemi, yakni wabah penyakit yang berjangkit serempak di mana-mana, meliputi daerah geografi yang luas. ${ }^{3}$ Sebagai epidemi yang telah menyebar antar negara atau benua, dan umumnya menjangkiti banyak orang. Sementara Epidemi adalah penyakit yang menular yang berjangkit dengan cepat di daerah yang luas dan menimbulkan banyak korban, misalnya penyakit yang tidak secara tetap berjangkit di daerah itu (wabah), ${ }^{4}$ merupakan istilah yang digunakan untuk meningkatkan jumlah kasus penyakit secara tiba-tiba pada suatu populasi di area tertentu.

Pengertian Coronavirus adalah suatu kelompok virus yang dapat menyebabkan penyakit pada hewan atau manusia. Beberapa jenis coronavirus diketahui menyebabkan infeksi saluran nafas pada manusia mulai dari batuk, pilek, hingga yang lebih serius seperti Middle East Respiratory Syndrome (MERS) dan Severe Acute Respiratory Syndrome (SARS). Coronavirus jenis baru yang ditemukan menyebabkan penyakit Covid-19.5

Gejala-gejala Covid-19 yang paling umum adalah demam, rasa lelah, dan batuk kering. Beberapa pasien mungkin mengalami rasa nyeri dan sakit, hidung tersumbat, pilek, sakit tenggorokan atau diare. Gejala-gejala yang dialami biasanya bersifat ringan dan muncul secara bertahap. Bebarapa orang yang terinfeksi tidak menunjukkan gejala apapun dan tetap merasa sehat. Sebagian besar (sekitar $80 \%$ ) orang yang terinfeksi berhasil pulih tanpa perlu perawatan khusus. Sekitar 1 dari 6 orang yang terjangkit Covid-19 menderita sakit parah dan

\footnotetext{
${ }^{1}$ https://www.who.int/indonesia/news/novel-coronavirus/qa-for-public, 20 April 2020.

${ }^{2}$ Ying-Ying Zheng, et.al., "COVID-19 and The Cardiovasculer System”, Nature Reviews Cardiology, 17, 5 March 2020, 259-260 (2020).

${ }^{3}$ Chulsum, Umi, e.al. Kamus Besar Bahasa Indonesia, Kashiko Publisher, Surabaya, 2014, hlm. 504.

${ }^{4}$ Ibid.

${ }^{5}$ https://www.who.int/indonesia/news/novel-coronavirus/qa-for-public, Op.Cit.
} 
kesulitan bernapas. Orang-orang lanjut usia dan orang dengan kondisi medis yang sudah ada sebelumnya seperti tekanan darah tinggi, gangguan jantung atau diabetes, punya kemungkinan lebih besar mengalami sakit lebih serius. ${ }^{6}$

Orang dapat tertular Covid-19 dari orang lain yang terjangkit virus ini. Covid-19 dapat menyebar dari orang ke orang melalui percikan-percikan dari hidung atau mulut yang keluar ketika orang yang terjangkit Covid-19 batuk dan bernapas. Percikan-percikan ini kemudian jatuh ke benda-benda dan permukaanpermukaan di sekitarnya. Orang yang menyentuh benda atau permukaan tersebut lalu menyentuk mata, hidung, atau mulutnya, dapat terjangkit Covid-19. Penularan Covid-19 juga dapat terjadi jika orang menghirup percikan yang keluar dari batuk atau napas orang yang terjangkit Covid-19. ${ }^{7}$

Pada 12 Maret 2020, Covid-19 telah dikonfirmasi sebanyak 125.048 orang di seluruh dunia, membawa angka kematian sekitar $3 \cdot 7 \%$, bandingkan dengan tingkat kematian kurang $1 \%$ dari influenza. Ada kebutuhan mendesak untuk perawatan yang efektif. Fokus di bidang medis saat ini adalah pada pengembangan terapi baru, termasuk antivirus dan vaksin. Akumulasi bukti menunjukkan bahwa subkelompok pasien dengan Covid-19 yang parah mungkin memiliki sindrom badai sitokin. Sehingga direkomendasikan identifikasi dan pengobatan hiperinflamasi menggunakan terapi yang sudah ada dan disetujui dengan profil keamanan yang terbukti dapat mengatasi kebutuhan mendesak untuk mengurangi meningkatnya kematian. ${ }^{8}$

Kasus Covid-19 yang fenomenal di Italia menunjukkan persentase pasien dalam perawatan intensif yang dilaporkan setiap hari antara 1 Maret dan 11 Maret 2020, secara konsisten antara 9\% dan $11 \%$ dari pasien yang terinfeksi aktif. Jumlah pasien yang terinfeksi sejak 21 Februari di Italia erat mengikuti tren eksponensial. Jika tren ini berlanjut selama 1 minggu kemudian, akan ada 30.000 pasien yang terinfeksi. Unit perawatan intensif akan berada pada kapasitas maksimum; hingga 4000 tempat tidur rumah sakit akan dibutuhkan pada pertengahan April 2020. ${ }^{9}$

Pengertian Coronavirus Disease 2019 (COVID-19) tidak ditemukan di dalam Peraturan Pemerintah Republik Indonesia Nomor 21 Tahun 2020 (PP 21/2020) tentang Pembatasan Sosial Berskala Besar dalam Rangka Percepatan Penanganan Coronavirus Disease 2019 (COVID-19).

Sebelum wabah penyakit ini memasuki negara Indonesia pada bulan Maret 2020, Indonesia telah memiliki Undang-Undang Republik Indonesia Nomor 6 Tahun 2018 tentang Kekarantinaan Kesehatan (UU 6/2018), yang diundangkan pada tanggal 8 Agustus 2018, sehingga ketika wabah ini memasuki Indonesia tinggal menyusun dan menetapkan aturan-aturan pelaksana untuk

\footnotetext{
${ }^{6}$ Qun Li, M.Med., et.al., (2020), Early Transmission Dynamics in Wuhan, China, of Novel Coronavirus-Infected Pneumonia, The New England Journal of Medicine, volume 382, issue 13, page 1199-1207.

${ }^{7}$ Ibid.

8 Mehta, Puja, et.al., "COVID-19: Consider Cytokine Storm Syndromes and Immunosupression”, The Lancet, Volume 395, issue 10229,P1033-1034, March 28,2020. Hal. 1.

${ }^{9}$ Remuzzi, Andrea, "COVID-19 and Italy: What Next ", The Lancet, Volume 395, Issue 10231, 11-17 April 2020, P. 1225-1228.
} 
mengimplementasikan penanganan lebih terperinci secara teknis terhadap Covid19. ${ }^{10}$ Keberadaan UU 6/2018 ini menunjukkan bahwa Indonesia telah mempersiapkan diri sebelum terjadinya wabah penyakit yang setara atau lebih serius dibandingkan dengan wabah-wabah penyakit sebelumnya.

Permasalannya adalah bagaimana Indonesia membuat solusi penanganan wabah penyakit Covid-19 dengan produk peraturan perundang-undangan.

\section{- $\quad$ Metode Penelitian}

Penelitian ini akan menjawab permasalahan bagaimana negara Indonesia melawan wabah Covid-19 melalui peraturan perundang-undangan. Penelitian dilakukan dengan metodologi yuridis normatif, dengan analisa kualitatif. Pendekatan yang digunakan adalah pendekatan perundang-undangan dan kasuskasus yang terjadi selama wabah Covid-19 pertama kali masuk di negara Indonesia sampai implementasi pertama kali dari pemerintah daerah atas peraturan perundang-undagan yang ditetapkan pemerintah pusat. Data-data pendukung yang digunakan adalah data dari Kementerian Kesehatan Republik Indonesia terkait jumlah penduduk yang terkonfimasi, sembuh dan meninggal akibat wabah Covid-19.

Penelitian ini akan menyampaikan produk peraturan perundang-undangan yang ditetapkan sebelum dan saat Covid-19 masuk di negara Indonesia, sehingga wabah ini dapat ditanggulagi.

\section{- Hasil Penelitian dan Pembahasan}

Wabah penyakit Covid-19 mulai masuk Indonesia pertama kali diumumkan langsung oleh Presiden Republik Indonesia, Joko Widodo, pada hari Senin, tanggal 2 bulan Maret 2020, yang menimpa dua warga Depok, Provinsi Jawa Barat, yakni seorang ibu yang berusia 64 tahun dan puterinya yang berusia 31 tahun. Namun bangsa Indonesia masih tetap percaya diri, menganggap bahwa wabah ini sulit memasuki dan berkembang di negara Indonesia, karena pelbagai asumsi-asumsi, yakni:

1. Negara Indonesia adalah negara tropis yang memiliki 2 (dua) musim, yakni musim panas dan musim hujan. Sedangkan virus ini tidak akan bisa bertahan di tempat yang panas;

2. Mayoritas bangsa Indonesia adalah memiliki gen bangsa Melayu, bukan Mongoloid seperti masyarakat Republik Rakyat Tiongkok;

3. Orang Indonesia memiliki kekayaan budaya kuliner terkait makanan dan minuman yang penuh dengan beraneka rempah-rempah yang bisa menjadi imun yang baik bagi penduduk Indonesia terhadap virus.

Asumsi-asumsi di atas sangat beralasan, baik sebagai bagian dari kekayaan budaya maupun secara ilmiah. Namun ketika wabah penyakit Covid-19 ini memasuki negara Indonesia dengan perkembangan yang cukup cepat dengan beberapa indikator, yakni jumlah orang yang terkonfirmasi Covid-19, Orang dalam Pemantauan (ODP), Pasien dalam Pengawasan (PDP), dan meninggal.

${ }^{10}$ Undang-Undang Republik Indonesia Nomor 6 Tahun 2018 tentang Kekarantinaan Kesehatan. 
Maka pemerintah mulai mengambil langkah-langkah persiapan penanganan dengan produk peraturan perundang-undangan.

Peraturan Perundang-undangan yang ditetapkan dalam perkembangan berikutnya adalah:

1. Keputusan Presiden Republik Indonesia Nomor 11 Tanun 2020 tentang Penetapan Kedaruratan Kesehatan Masyarakat Corona Virus Disease 2019 (Covid-19);

2. Peraturan Pemerintah Pengganti Undang-Undang Republik Indonesia Nomor 1 Tahun 2020 tentang Kebijakan keuangan Negara dan Stabilitas Sistem Keuangan untuk penangangan Pandemi Corona Virus Disease 2019 (Covid19) dan/atau dalam Rangka Menghadapi Ancaman yang Membahayakan Perekonomian Nasional dan/atau Stabilitas Sistem Keuangan;

3. Peraturan Pemerintah Republik Indonesia Nomor 21 Tahun 2020 tentang Pembatasan Sosial Berskala Besar dalam Rangka Percepatan Penanganan Corona Virus Disease 2019 (Covid-19).

Ketiga peraturan perundang-undangan di atas ditetapkan pada tanggal yang sama, yakni pada tanggal 31 Maret 2020. Sehingga bisa disimpulkan bahwa kemungkinan besar proses penyusunan dan harmonisasi peraturan perundangundangan dilakukan oleh tim penyusun yang sama. Sedangkan Presiden tinggal memberikan arah, tujuan, mengevaluasi dan menetapkan saja.

Keputusan Presiden Republik Indonesia Nomor 11 Tanun 2020 tentang Penetapan Kedaruratan Kesehatan Masyarakat Corona Virus Disease 2019 (Covid-19) menetapkan bahwa Covid-19 sebagai jenis penyakit yang menimbulkan kedaruratan kesehatan masyarakat. Dampak kedaruratan ini pada perkembangannya tidak hanya dampak dari negara Republik Rakyat Tiongkok ke Indonesia saja, tapi menyebar ke lebih dari 200 negara di dunia. Sehingga Covid19, menjadi sumber bencana kemanusiaan secara global. ${ }^{11}$

Berdasarkan Keputusan Presiden tersebut, maka pemerintah wajib untuk melakukan upaya penanggulangan sesuai dengan peraturan perundang-undangan yang berlaku. Sehingga ada kewenangan atributif yang diberikan oleh peraturan perundang-undangan untuk mengatasi pandemi Covid-19 ini.

Peraturan Pemerintah Pengganti Undang-Undang Republik Indonesia Nomor 1 Tahun 2020 tentang Kebijakan keuangan Negara dan Stabilitas Sistem Keuangan untuk penangangan Pandemi Corona Virus Disease 2019 (Covid-19) dan/atau dalam Rangka Menghadapi Ancaman yang Membahayakan Perekonomian Nasional dan/atau Stabilitas Sistem Keuangan. Peraturan ini adalah produk hukum yang paling menjadi polemik di kwartal pertama tahun 2020 di Indonesia, sehingga langsung digugat oleh kelompok masyarakat ke Mahkamah Konstitusi. Peraturan ini melakukan revisi dengan menambah anggaran khusus untuk menangani Covid-19 sebesar Rp. 405,1 triliun, terkait kebijakan transfer ke daerah dan Dana Desa, antara lain berupa:

1. Peyesuaian alokasi dana bagi hasil dilakukan berdasarkan perkembangan perekonomian dan/atau penerimaan negara;

11 Keputusan Presiden Republik Indonesia Nomor 11 Tanun 2020 tentang Penetapan Kedaruratan Kesehatan Masyarakat Corona Virus Disease 2019 (Covid-19). 
2. Penyesuaian alokasi dana, alokasi dana umum perdaerah berdasarkan kriteria tertentu yang ditetapkan menteri keuangan;

3. Penambahan/pengurangan alokasi dana transfer khusus karena kondisi tertentu yang membutuhkan anggaran mendesak; dan/atau

4. Penyesuaian pagu anggaran dana desa;

5. Mengutamakan penggunaan dana desa, yang dapat digunakan antara lain untuk bantuan langsung tunai kepada penduduk miskin di desa dan kegiatan penanganan pandemi Covid-19. ${ }^{12}$

Peraturan Pemerintah Republik Indonesia Nomor 21 Tahun 2020 tentang Pembatasan Sosial Berskala Besar dalam Rangka Percepatan Penanganan Corona Virus Disease 2019 (Covid-19), memberikan kepastian bahwa diantara beberapa pilihan yang diberikan oleh Undang-Undang Nomor 6 Tahun 2018 tentang Kekarantinaan Kesehatan, maka pilihan yang diambil oleh pemerintah adalah Pembatasan Sosial Berskala Besar. ${ }^{13}$ Pemerintah tidak berani mengambil keputusan Karantina Wilayah, karena dana yang harus ditanggung oleh negara sangat besar, negara wajib menanggung kebutuhan dasar seluruh warga di wilayah yang dikarantina, risikonya adalah kebangkrutan ekonomi negara.

Pilihan Pembatasan Sosial Berskala Besar adalah pilihan yang paling rasional, karena hanya terkait meliburkan jam kerja, jam sekolah, tempat ibadah dan kegiatan masyarakat yang menhadirkan kerumunan, agar semua kegiatan tersebut dilakukan dari rumah. Pilihan ini banyak menerima kritik dari beberapa kelompok masyarakat, bahwa pemerintah pusat dianggap hanya mengambil keputusan dengan mengalihkan tanggung-jawabnya kepada pemerintah daerah bersama menteri kesehatan.

3 (tiga) produk peraturan perundang-undangan tersebut di atas kemudian ditindaklanjuti dengan beberapa peraturan perundang-undangan yang lebih bawah secara hirarkhi, yakni:

1. Peraturan Menteri Kesehatan Republik Indonesia Nomor 9 Tahun 2020 tentang Pedoman Pembatasan Sosial Berskala Besar dalam Rangka Percepatan Penanganan Corona Virus Disease 2019 (Covid);

2. Keputusan Menteri Kesehatan Republik Indonesia Nomor HK.01.07/Menkes/231/2020 tentang Tim Penetapan Pembatasan Sosial Berskala Besar dalam Rangka Percepatan Penanganan Corona Virus disease 2019 (Covid-19).

Kedua peraturan perundang-undangan yang ditetapkan oleh Menteri Kesehatan Republik Indonesia tersebut di atas, yang ditetapkan pada tanggal 3 April 2020, adalah implementasi peratururan perundang-undangan sebelumnya yang telah ditetapkan oleh Presiden.

\footnotetext{
12 Peraturan Pemerintah Pengganti Undang-Undang Republik Indonesia Nomor 1 Tahun 2020 tentang Kebijakan keuangan Negara dan Stabilitas Sistem Keuangan untuk penangangan Pandemi Corona Virus Disease 2019 (Covid-19) dan/atau dalam Rangka Menghadapi Ancaman yang Membahayakan Perekonomian Nasional dan/atau Stabilitas Sistem Keuangan.

13 Peraturan Pemerintah Republik Indonesia Nomor 21 Tahun 2020 tentang Pembatasan Sosial Berskala Besar dalam Rangka Percepatan Penanganan Corona Virus Disease 2019 (Covid19)
} 
Pada tahap ini pelaksanaan status "Pembatasan Sosial Berskala Besar" belum dapat dilaksanakan apabila belum ada permohonan yang diajukan oleh para kepala daerah di Indonesia, baik Gubernur, Bupati atau Wali Kota, kepada Menteri Kesehatan Republik Indonesia untuk ditetapkan wilayah daerahnya dalam status "Pembatasan Sosial Berskala Besar". Sehingga implementasi peraturan baru benar-benar bisa ditegakkan ketika sudah ada peraturan pelaksana di tingkat Bupati/Walikota.

Penetapan status "Pembatasan Sosial Berskala Besar" adalah status yang lebih ringan dibandingkan dengan status "Karantina Wilayah". Keduanya memiliki konsekuensi sosial, politik dan ekonomi yang berbeda untuk dilakukan, baik oleh pemerintah daerah maupun pemerintah pusat.

Penetapan status "Pembatasan Sosial Berskala Besar" hanya mewajibkan wilayah melaksanakan minimal:

1. Peliburan sekolah dan tempat kerja;

2. Pembatasan keagamaan; dan/atau

3. Pembatasan kegiatan di tempat atau fasilitas umum. ${ }^{14}$

Pada tanggal 7 April 2020, provinsi Daerah Khusus Ibukota (DKI) Jakarta adalah provinsi pertama yang ditetapkan oleh Menteri Kesehatan sebagai wilayah yang berstatus "Pembatasan Sosial Berskala Besar", setelah sebelumnya ada permohonan dari Gubernur DKI Jakarta kepada Menteri Kesehatan. Walaupun asal mula pandemi Covid-19 dari kota Depok Jawa Barat, namun penyebarannya massif terjadi di DKI Jakarta, sehingga pemerintah DKI Jakarta lebih dahulu melakukan pengajuan "Pembatasan Sosial Berskala Besar" kepada Menteri Kesehatan dari pada Jawa Barat.

Penetapan tersebut tertuang di dalam Keputusan Menteri Kesehatan Republik Indonesia Nomor HK.01.07/Menkes/239/2020 tentang Penetapan Pembatasan Sosial Berskala Besar di Wilayah Provinsi DKI Jakarta dalam Rangka Percepatan Penangan Corona Virus Disease 2019 (Covid-19), ditetapkan di Jakarta, pada tanggal 7 April 2020. ${ }^{15}$

Pada tanggal yang sama, 34 Provinsi selain DKI Jakarta, serta 514 Kabupaten/Kota di Indonesia masih belum berstatus "Pembatasan Sosial Berskala Besar". Hampir semua provinsi dan kabupaten/kota mengkhawatirkan ketahanan ekonomi sebagai alasan utama untuk hati-hati dalam mengajukan permohonan kepada Menteri Kesehatan untuk ditetapkan status "Pembatasan Sosial Berskala Besar" terhadap wilayahnya.

Padahal satu hari sebelumnya, yakni pada hari Senin, tanggal 6 April 2020, jam 15.42 Waktu Indonesia bagian Barat (WIB), Pemerintah Indonesia mengumumkan melalui Kementerian Kesehatan, bahwa kasus yang terkonfirmasi Covid-19 sebanyak 2.491 orang, tersebar di 32 provinsi. Kasus penyebaran Covid-

${ }^{14}$ Peraturan Pemerintah Republik Indonesia Nomor 21 Tahun, op.cit.

${ }^{15}$ Keputusan Menteri Kesehatan Republik Indonesia Nomor HK.01.07/Menkes/239/2020 tentang Penetapan Pembatasan Sosial Berskala Besar di Wilayah Provinsi DKI Jakarta dalam Rangka Percepatan Penangan Corona Virus Disease 2019 (Covid-19) 
19 tertinggi terjadi di provinsi DKI Jakarta, kemudian disusul oleh Jawa Barat dan Jawa Timur. ${ }^{16}$

Data sementara pada tanggal dan jam tersebut di atas yang terjadi di 32 Provinsi yang terdampak Covid-19, sebagaimana yang selalu disampaikan melalui website kementerian kesehatan, adalah sebagai berikut:

1. Provinsi DKI Jakarta:

Terkonfirmasi : 1.232 kasus;

Semubh : $: 65$ Kasus

Meninggal : 99 kasus.

2. Provinsi Jawa Barat:

Terkonfirmasi : 263 kasus;

Sembuh : 13 kasus;

Meninggal : 29 kasus.

3. Provinsi Jawa Timur:

Terkonfirmasi : 263 kasus;

Sembuh : 38 kasus;

Meninggal : 14 kasus.

4. Provinsi Banten:

Terkonfirmasi : 187 kasus;

Sembuh : 7 kasus;

Meninggal : 17 kasus.

5. Provinsi Jawa Tengah:

Terkonfirmasi : 132 kasus

Sembuh : 14 kasus;

Meninggal : 22 kasus.

6. Provinsi Sulawesi Selatan:

Terkonfirmasi : 113 kasus;

Sembuh : 19 kasus;

Meninggal : 6 kasus.

7. Provinsi Bali:

Terkonfismasi : 43 kasus;

Sembuh : 18 kasus;

Meninggal : 2 kasus.

8. Provinsi Daerah Istimewa Yogyakarta:

Terkonfirmasi : 40 kasus;

Sembuh : 1 kasus;

Meninggal : 3 kasus.

9. Provinsi Kalimantan Timur

Terkonfirmasi : 31 kasus;

Sembuh : 1 kasus;

Meninggal : 1 kasus.

10. Provinsi Sumatera Utara:

Terkonfirmasi : 26 orang;

Sembuh : 0 kasus;

Meninggal : 4 kasus.

11. Provinsi Papua:

${ }^{16} \mathrm{https}: / /$ www.kompas.com/tren/read/2020.04/06/171111665/2491-orang-positif-cofid-19di-indonesia-ini-rincian-kasus-di-32-provinsi?page=1, 25 April 2020. 
Terkonfirmasi : 26 kasus;

Sembuh : 3 kasus;

Meninggal : 2 kasus.

12. Provinsi Kalimantan Tengah:

Terkonfirmasi : 20 kasus;

Sembuh : 4 kasus;

Meninggal : 0 kasus.

13. Provinsi Sumatera Barat:

Terkonfirmasi : 18 kasus;

Sembuh : 0 kasus;

Meninggal : 0 kasus.

14. Provinsi Kalimantan Selatan:

Terkonfirmasi : 18 kasus;

Sembuh : 0 kasus;

Meninggal : 0 kasus.

15. Provinsi Sumatera Selatan:

Terkonfirmasi : 16 kasus;

Sembuh : 1 kasus;

Meninggal : 2 kasus.

16. Provinsi Kalimantan Utara:

Terkonfirmasi : 15 kasus;

Sembuh : 0 kasus;

Meninggal : 0 kasus.

17. Provinsi Riau:

Terkonfirmasi : 12 kasus;

Sembuh : 1 kasus;

Meninggal : 0 kasus.

18. Provinsi Lampung:

Terkonfirmasi : 12 kasus;

Sembuh : 0 kasus;

Meninggal : 1 kasus.

19. Provinsi Kalimantan Barat:

Terkonfirmasi : 12 kasus;

Sembuh : 2 kasus;

Meninggal : 2 kasus.

20. Provinsi Nusa Tenggara Barat:

Terkonfirmasi : 10 kasus;

Sembuh : 0 kasus;

Meninggal : 0 kasus.

21. Provinsi Riau:

Terkonfirmasi : 9 kasus;

Sembuh : 2 kasus;

Meninggal : 1 kasus.

22. Provinsi Sulawesi Tenggara:

Terkonfirmasi : 7 kasus;

Sembuh : 1 kasus;

Meninggal : 0 kasus.

23. Provinsi Daerah Istimewa Aceh:

Terkonfirmasi : 5 kasus;

Sembuh : : 0 kasus; 
Meninggal : 1 kasus.

24. Provinsi Sulawesi Utara:

Terkonfirmasi : 5 kasus;

Sembuh : 1 kasus;

Meninggal : 0 kasus.

25. Provinsi Sulawesi Tengah:

Terkonfirmasi : 4 kasus;

Sembuh : : 0 kasus;

Meninggal : 0 kasus.

26. Provinsi Jambi:

Terkonfimasi : 2 kasus;

Sembuh : 0 kasus;

Meninggal : 0 kasus.

27. Provinsi Bengkulu:

Terkonfirmasi : 2 kasus;

Sembuh : 0 kasus;

Meninggal : 1 kasus.

28. Provinsi Kepualauan Bangka Belitung:

Terkonfirmasi : 2 kasus;

Sembuh : 0 kasus;

Meninggal : 1 kasus.

29. Kepulauan Sulawesi Barat:

Terkonfirmasi : 2 kasus;

Sembuh : 0 kasus;

Meninggal : 0 kasus.

30. Provinsi Papua Barat:

Terkonsentrasi : 2 kasus;

Sembuh : 0 kasus;

Meninggal : 1 kasus.

31. Provinsi Maluku:

Terkonfirmasi : 1 kasus;

Sembuh : 1 kasus;

Meninggal : 0 kasus.

32. Provinsi Maluku Utara:

Terkonfirmasi : 1 kasus;

Sembuh : 0 kasus;

Meninggal :0 kasus.

Berdasarkan data di atas, jumlah total yang terkonfirmasi positif Covid-19 adalah sebanyak 2.491 kasus. Dari jumlah tersebut terdapat sebanyak 2.090 orang tengah menjalani perawatan medis, 192 orang dinyatakan pulih atau negatif Covid-19, sedangkan yang meninggal sebanyak 209 orang. Ada 3 (tiga) Provinsi yang masih mampu bertahan dari penyebaan wabah Covid-19, yakni Provinsi Bengkulu, Provinsi Gorontalo dan Provinsi Nusa Tenggara Timur.

Berdasarkan data tersebut, pada mulanya hanya Provinsi DKI Jakarta saja yang serius merespon peraturan perundang-undangan yang telah ditetapkan oleh pemerintah pusat, dengan telah mengajukan permohonan kepada Menteri Kesehatan Republik Indonesia untuk ditetapkan sebagai wilayah dengan status "Pembatasan Sosial Berskala Besar". Permohonan tersebut telah dikabulkan pada 
tanggal 6 April 2020, yang diterapkan pada tanggal 10 April 2020. Sedangkan wilayah-wilayah lainnya baik di tingkat provinsi maupun kabupaten/kota, belum mengajukan permohonan untuk ditetapkan sebagai wilayah dengan status "Pembatasan Sosial Berskala Besar".

Ada 2 alasan utama wilayah-wilayah tidak segera merespon peraturan peraturan terkait "Pembatasan Sosial Berskala Besar", yakni:

1. Risiko Ekonomi:

Wilayah-wilayah tidak siap dengan risiko ekonomi yang ditimbulkan apabila status "Pembatasan Sosial Berskala Besar" diterapkan. Apalagi setiap wilayah memiliki ketahanan ekonomi yang berbeda-beda;

2. Risiko Sosial:

Wilayah-wilayah tidak siap dengan risiko sosial yang ditimbulkan akibat diterapkannya status "Pembatasan Sosial Berskala Besar". Apabila ruang gerak masyarakat dibatasi untuk beraktifitas dalam profesi, pendidikan, keagamaan, dan sosial lainnya, maka dipastikan akan muncul reaksi-reaksi akibat pembatasan tersebut. Sedangkan bila para kepala daerah di wilayah tersebut tidak bisa mengelola dan pengendalikan reaksi-reaksi sosial yang muncul, maka akan timbul kekacauan-kekacauan dalam masyarakat.

Pertanyaan yuridisnya adalah apa dasar hukum daerah-daerah selain DKI Jakarta dalam menangani Pandemi Covid-19?. Maka jawabannya adalah, bahwa daerah-daerah tersebut masih menggunakan landasan hukum: Surat Edaran, yang dibuat oleh masing-masih gubernur. Ada bebarapa Surat Edaran yang dapat dilacak terkait penanganan Pandemi Covid-19, yang disusun sesuai urutan tanggal penetapannya, yakni:

1. Surat Edaran Gubernur Daerah Istimewa Aceh Nomor: 440/4820 tentang Cegah Virus Corona Melalui Ibadah, Perilaku Hidup Bersih dan Sehat, tertanggal 12 Maret 2020. Surat Edaran ini ditujukan kepada Bupati/Walikota se-Aceh, para Rektor Perguruan Tinggi/Swasta, para Pimpinan Instansi Vertikal, para Kepala Satuan Kerja Perangkat Aceh, para Kakanwil kementerian, para Pimpinan BUMN/BUMD, para Pimpinan Perbankan dan seluruh lapisan masyarakat Aceh; ${ }^{17}$

2. Surat Edaran Gubernur Jawa Timur Nomor: 420/1780/101.1/2020, tanggal 15 Maret 2020, Perihal Peningkatan Kewaspadaan Corona Virus Disease 2019 (Covid-19). Isi dari Surat Edaran ini adalah bersifat himbauan-himbauan, khususnya kepada peserta didik di sekolah dan para guru terkait kegiatan belajar untuk waspada terhadap pandemi Covid-19; ${ }^{18}$

3. Surat Edaran Gubernur DKI Jakarta Nomor: 2/SE/2020, tanggal 16 Maret 2020, tentang Penyesuaian Sistem Kerja Pegawai dalam Upaya Pencegahan Penyebaran Virus Corona atau Covid-19 di Lingkungan Pemerintah Provinsi DKI Jakarta. Surat Edaran diterbitkan ini dalam rangka menindaklanjuti Surat Edaran Menteri Pendayagunaan Aparatur Sipil Negara (ASN) dan Reformasi Birokrasi Nomor 19 Tahun 2020 tentang Penyesuaian Sistem Kerja ASN

\footnotetext{
${ }^{17}$ Surat Edaran Gubernur Daerah Istimewa Aceh Nomor: 440/4820 tentang Cegah Virus Corona Melalui Ibadah, Perilaku Hidup Bersih dan Sehat

${ }^{18}$ Surat Edaran Gubernur Jawa Timur Nomor: 420/1780/101.1/2020, tanggal 15 Maret 2020,

Perihal Peningkatan Kewaspadaan Corona Virus Disease 2019 (Covid-19)
} 
dalam Upaya Pencegahan Penyebaran Covid-19 di Lingkungan Instansi Pemerintah; ${ }^{19}$

4. Surat Edaran Gubernur Sumatera Utara Nomor: 440/2666/2020 tentang Peningkatan Kewaspadaan terhadap Resiko Penularan Infeksi Corona Virus Disease (Covid-19) di Sumatera Utara, tertanggal 17 Maret 2020. Surat Edaran ini berisi tentang langkah-langkah proses belajar mengajar di lembaga pendidikan dalam suasan Pandemi Covid-19, seperti menggunakan cara belajar jarak jauh;

5. Surat Edaran Gubernur Kalimantan Tengah Nomor: 443.1/25/2020 tentang Pengawasan dan Pencegahan Virus Covid-19 di Perbatasan dan Pesisir Wilayah Kalimantan Tengah, tertanggal 19 Maret 2020. Surat Edaran ini menghimbau kepada seluruh Bupati dan Wali Kota se-Kalimantan Tengah, untuk selalu melakukan pengawasan dan pemeriksaan terhadap semua angkutan umum (penumpang dan awak) yang melayani angkutan luar negeri dan dalam negeri serta wilayah perbatasan Kalimantan Timur, Kalimantan Barat, Kalimantan Selatan, baik langsung maupun transit. Pengawasan Ketat juga dilakukan di wilayah-wilayah pesisir / kampung-kampung nelayan yang melintas di Provinsi dalam negeri dan luar negeri. Serta mensinergikan bersama non-TNI, Polri, Danramil, Kapolsek dan Perangkat Desa Kewilayahan (Camat, Lurah dan Kepala Desa); ${ }^{20}$

6. Surat Edaran Gubernur DIY Nomor: 2/SE/III/2020 tentang Peningkatan Kewaspadaan Terhadap Risiko Penularan Infeksi Corona Virus Disease (Covid-9) dari Pendatang/Pemudik ke Daerah Istimewa Yogyakarta, tertanggal 27 Maret 2020. Surat Edaran ini antara lain berisi himbauan kepada Para Pendatang/Pemudik melakukan isolasi secara mandiri selama 14 (empat belas) hari di rumah sejak hari kedatangan, menggunakan kamar terpisah dengan anggota keluarga lainnya, menggunakan masker selama isolasi mandiri. Sedangkan bagi warga masyarakat wajib melaporkan kedatangan saudaranya/anggota keluarganya kepada aparat pemerintah setempat, membatasi diri untuk tidak banyak berinteraksi dan kontak fisik dengan pendatang/pemudik. Pemerintah Desa/Kelurahan wajib membuat Posko Tangguh Covid-19 serta berkoordinasi dengan pimpinan wilayah kecamatan/Kepanewon/ Kemantren; ${ }^{21}$

Itu hanya beberapa contoh kebijakan yang telah diambil oleh para Gubernur di daerahnya masing-masing.

Dalam ranah teoritis hukum administrasi negara, ada polemik yang terjadi di kalangan akademisi, yakni banyak ditetapkannya "Surat Edaran", yang

\footnotetext{
${ }^{19}$ Surat Edaran Gubernur DKI Jakarta Nomor: 2/SE/2020, tanggal 16 Maret 2020, tentang Penyesuaian Sistem Kerja Pegawai dalam Upaya Pencegahan Penyebaran Virus Corona atau Covid-19 di Lingkungan Pemerintah Provinsi DKI Jakarta.

${ }^{20}$ Surat Edaran Gubernur Kalimantan Tengah Nomor: 443.1/25/2020 tentang Pengawasan dan Pencegahan Virus Covid-19 di Perbatasan dan Pesisir Wilayah Kalimantan Tengah, tertanggal 19 Maret 2020.

${ }^{21}$ Surat Edaran Gubernur DIY Nomor: 2/SE/III/2020 tentang Peningkatan Kewaspadaan Terhadap Risiko Penularan Infeksi Corona Virus Disease (Covid-9) dari Pendatang/Pemudik ke Daerah Istimewa Yogyakarta.
} 
seharusnya tidak boleh berisi norma-norma, kewajiban dan larangan yang berisi sanksi-sanksi. Karena Surat Edaran adalah merupakan kebijakan yang berisi himbauan untuk memperjelas peraturan yang telah ada sebelumnya terjadi. Surat Edaran tidak termasuk dalam hirarkhi peraturan perundang-undangan. Biasanya aparat pemerintah yang bertugas menegakkan terlaksananya Surat Edaran adalah bukan aparat kepolisian, tapi Satuan Polisi Pamong Praja (Satpol PP). Namun dalam penanganan penanggulangan pandemi Covid-19 ini, aparat kepolisian seringkali terlihat turut serta terlibat dalam menegakkan kebijakan Gubernur ini.

Beberapa Surat Edaran yang ditetapkan dalam kondisi darurat kesehatan bisa menjadi masalah ketika kondisi negara normal kembali, risiko tanggunggugat terhadap kebijakan pemerintah dalam kondisi darurat seperti ini. Permasalahan menjadi semakin besar ketika para penegak hukum memproses gugatan tersebut dalam konteks negara dalam keadaan normal, bukan dalam konteks negara dalam keadaan darurat, dimana pemerintah dapat melakukan diskresi dengan dua alasan, yakni demi kepentingan umum dan tidak melanggar peraturan perundang-undangan. ${ }^{22}$

Dasar hukum aparat kepolisian dalam menegakkan kebijakan Gubernur ini adalah Maklumat Kapolri Nomor Mak/2/III/2020 tentang Kepatuhan Terhadap Kebijakan Pemerintah dalam Penanganan Penyebaran Virus Corona. Dalam maklumat ini menyatakan bahwa Polri senantiasa mengacu asas "Keselamatan Rakyat Merupakan Hukum Tertinggi" (Salus Populi Suprema Lex Esto), dengan tidak mengadakan kegiatan sosial kemasyarakatan yang menyebabkan berkumpulnya massa dalam jumlah banyak, pertemuan sosial, budaya, keagamaan dan aliran kepercayaan dalam bentuk seminar, lokakarya, sarasehan, konser musik, pekan raya, festival, bazaar, pasar malam, pameran, resepsi keluarga, kegiatan olahraga, kesenian, jasa hiburan, unjuk rasa, pawai, karnaval, dan kegiatan lainnya yang menjadikan berkumpulnya massa.

Tindakan penegakan hukum yang dilakukan oleh aparat kepolisian mendapat tanggapan yang beragam, termasuk oleh Komisi Nasional Hak Asasi Manusia dan Yayasan Lembaga Bantuan Hukum Indonesia, terkait pembubaran tempat umum, karena dianggap melanggar hak asasi manusia, sedangkan aturan terkait larangan tersebut belum ditetapkan oleh pemerintah daerah tingkat kabupaten/kota.

Kemudian setelah beberapa waktu berlalu, pada 8 April 2020 Gubernur Jawa Barat mengajukan permohonan yang sama seperti DKI Jakarta kepada Menteri Kesehatan untuk status "Pembatasan Sosial Berskala Besar", tetapi terbatas pada wilayah Kabupaten Bogor, Kota Bogor, Kota Depok, Kabupaten Depok, Kabupaten Bekasi, Kota Bogor, dan Kota Bogor. dan Kota Bekasi. Permintaan ini dikabulkan pada 11 April 2020, melalui Keputusan Menteri Kesehatan Republik Indonesia Nomor HK.01.07/Menkes/248/2020 tentang Penetapan Pembatasan Sosial Berskala Besar di Wilayah Kabupaten Bogor, Kota Bogor, dan Kabupaten Bekasi, dan kota Bekasi, Provinsi Jawa Barat dalam

${ }^{22}$ Ridwan H.R., Hukum Administrasi Negara (Edisi Revisi), PT. RajaGrafindo Perkasa, Depok, 2018, hal. 155. 
Rangka Percepatan Penanganan Corona Virus Disease 2019 (Covid-19). ${ }^{23}$ Provinsi Jawa Barat adalah provinsi dengan penduduk terbanya dibandingkan dengan provinsi-provinsi yang lain, yakni 48.037.600 penduduk, berarti 18,3 persen dari seluruh penduduk di Indonesia yang berjumlah sebesar 261.890.900 jiwa. Sehingga dari pertimbangan tersebut, selain karena tingkat penyebarannya yang terus meningkat, maka Provinsi Jawa Barat ditetapkan oleh Menteri Kesehatan berstatus Pembatasan Sosial Berskala Besar, setelah provinsi DKI Jakarta.

Pada tanggal 12 April 2020, Menteri Kesehatan Republik Indonesia, Terawan Agus Putranto, juga menetapkan status untuk tiga wilayah di Provinsi Banten, yakni Kabupaten Tangerang, Kota Tangerang, dan Kota Tangerang Selatan dalam rangka percepatan penanganan Covid-19, melalui Keputusan Menteri Kesehatan Nomor HK.01.07/Menkes/249/2020.

Provinsi Banten, sebagaimana provinsi Jawa Barat, adalah provinsi penyanggah provinsi DKI Jakarta, sehingga penyebaran virus Covid-19, dipastikan menyebar lebih dahulu ke Jawa Barat dan Banten. Hal ini akibat dari arus keluar dan masuknya masyarakat yang bekerja dan akses perdagangan yang sangat tergantung dengan pusat pemerintahan dan perdagangan di DKI Jakarta.

Pada tanggal 19 April 2020 Gubernur Jawa Timur mengadakan rapat dengan Walikota Surabaya, Bupati Sidoarjo dan Bupati Gresik. Rapat tersebut terkesan berat dalam mengambil keputusan, karena sebelumnya telah ada pernyataan penolakan dari walikota Surabaya dan Bupati Sidoarjo. Namun akhirnya rapat tersebut memutuskan pengajuan Pembatasan Sosial Berskala Besar untuk tiga kota/kabupaten tersebut tetap diajukan, yakni seluruh wilayah Surabaya, 14 (empat belas) dari 18 (delapan belas) Kecamatan di Sidoarjo, dan beberapa kecamatan di kabupaten Gresik.

Surat permohonan dari Gubernur Jawa Timur dijawab oleh Menteri Kesehatan pada tanggal 21 April 2020 melalui Keputusan Menteri Kesehatan Nomor: HK.01.07/Menkes/264/2020 tentang Penetapan Pembatasan Sosial Berskala Besar di Wilayah Kota Surabaya, Kabupaten Sidoarjo, dan Kabupaten Gresik, Provinsi Jawa Timur dalam Rangka Percepatan dalam Rangka Percepatan Penanganan Corona Virus Disease 2019 (Covid-19). Ketetapan ini berlaku untuk seluruh wilayah kota Surabaya, kabupaten Sidoarjo, dan kabupaten Gresik, bukan sebagian kecamatan di kabupaten Sidoarjo dan Gresik, sebagaimana yang diharapkan oleh dua bupati tersebut.

Kemudian pada tanggal 23 April 2020 Gubernur Jawa Timur, Khofifah Indar Parawansa, secara resmi menetapkan Peraturan Gubernur Jawa Timur Nomor 18 Tahun 2020 tentang Pedoman Pembatasan Sosial Berskala Besar dalam penangana Covid-19 di Provinsi Jawa Timur. Kemudian diikuti implementasinya dengan Peraturan Walikota Surabaya, Peraturan Bupati Sidoarjo, dan Walikota Gresik.

\footnotetext{
${ }^{23}$ Keputusan Menteri Kesehatan Republik Indonesia Nomor HK.01.07/Menkes/248/2020 tentang Penetapan Pembatasan Sosial Berskala Besar di Wilayah Kabupaten Bogor, Kota Bogor, dan Kabupaten Bekasi, dan kota Bekasi, Provinsi Jawa Barat dalam Rangka Percepatan Penanganan Corona Virus Disease 2019 (Covid-19).
} 
Dalam penegakannya Gubernur Jawa Timur menetapkan Keputusan Gubernur Jawa Timur Nomor 188/108/KPTS/013/2020 tentang Status Keadaan Darurat Bencana Wabah Penyakit Akibat Corona Virus Disease 2019 (Covid19). ${ }^{24}$

Kemudian disusul dengan Keputusan Gubernur Jawa Timur Nomor 188/202/KPTS/013/2020 tentang Pemberlakuan Pembatasan Sosial Berskala Besar dalam Penanganan Corona Virus Disease 2019 (Covid-19) di Wilayah Kota Surabaya, Kabupaten Sidoarjo, dan Kebupaten Gresik. Di dalamnya memuat pemberlakuan Pembatasan Sosial Berskala Besar sejak tanggal 28 Maret 2020 sampai dengan 11 April 2020. ${ }^{25}$

Pemberlakuan Pembatasan Sosial Berskala Besar di Wilayah Kota Surabaya, kabupaten Sidoarjo dan kabupaten Gresik, diperpanjang lagi sejak tanggal 12 April 2020 sampai dengan 25 April 2020, yang dituangkan dalam Keputusan Gubernur Jawa Timur Nomor 188/219/KPTS/013/2020 tentang Perpanjangan Pemberlakuan Pembatasan Sosial Berskala Besar dalam Penanganan Corona Virus Disease 2019 (Covid-19) di Wilayah Kota Surabaya, Kabupaten Sidoarjo, dan Kabupaten Gresik. ${ }^{26}$

Pertimbangan perpanjangan pemberlakuan Pembatasan Sosial Berskala Besa di kota tersebut yang terkonfirmasi positif Corona tidak mengalami penuruan yang signifikan, sehingga dalam masa perpanjangan ini penegakannya ditingkatkan, tidak hanya melalui himbauan saja, tapi juga melalui penegakan hukum, seperti penahanan Kartu Tanda Penduduk (KTP), atau terhambatnya perpanjangan Surat Izin Mengemudi (SIM), apabila melanggar peraturan terkait Covid-19. Selain itu menambah jumlah personil penegak hukum, baik dari pihak kepolisian, Satuan Polisi Pamong Praja (Satpol PP), dan petugas dari Dinas Perhubungan, yang menjaga di beberapa pos check point yang semakin diperbanyak. Kualitas penanggulangannya juga semakin ditingkatkan menjadi lebih simpatik, yakni dengan membagikan masker gratis bagi pengguna yang belum memakai masker di jalan raya, dan melakukan penyemprotan disinfektan untuk kendaraan (benda padat) yang digunakan oleh pemakai jalan.

Data Kementerian Kesehatan Republik Indonesia pada tanggal 13 Mei 2020, kasus Covid-19 mencapai 15.438 kasus yang positif corona, pasien yang sembuh 3.287 orang, sedangkan yang meninggal mencapai 1.028 orang, yang masih dirawat dirawat 11.123 orang, tersebar di 34 Propinsi. ${ }^{27}$ Bandingkan dengan ketika permohonan PSBB pertama kali diajukan oleh DKI Jakarta, kemudian dikabulkan oleh Menteri Kesehatan, yakni pada tanggal 6 April 2020, kasus yang terkonfirmasi Covid-19 sebanyak 2.491 orang, tersebar di 32 provinsi.

24 Keputusan Gubernur Jawa Timur Nomor 188/108/KPTS/013/2020 tentang Status Keadaan Darurat Bencana Wabah Penyakit Akibat Corona Virus Disease 2019 (Covid-19)

${ }^{25}$ Keputusan Gubernur Jawa Timur Nomor 188/202/KPTS/013/2020 tentang Pemberlakuan Pembatasan Sosial Berskala Besar dalam Penanganan Corona Virus Disease 2019 (Covid-19) di Wilayah Kota Surabaya, Kabupaten Sidoarjo, dan Kebupaten Gresik

${ }^{26}$ Keputusan Gubernur Jawa Timur Nomor 188/219/KPTS/013/2020 tentang Perpanjangan Pemberlakuan Pembatasan Sosial Berskala Besar dalam Penanganan Corona Virus Disease 2019 (Covid-19) di Wilayah Kota Surabaya, Kabupaten Sidoarjo, dan Kabupaten Gresik.

${ }^{27} \mathrm{https} / / /$ www.kompas.com/covid-19, 13 Mei 2020, jam 22.30 Wib. 
Terjadi lonjakan 444,5 \% sejak pemberlakuan Pembatasan Sosial Berskala Besar yang dimulai di DKI Jakarta, Jawa Barat, Banten dan Jawa Timur, mulai 6 April 2020 sampai dengan 13 Mei 2020.

Cara Indonesia menanggulangi Covid-19 dengan praturan perundangundangan ternyata memang tidak bisa menghentikan kasus Covid-19, namun mampu memperlambat. Pernyataan Presiden Joko Widodo di akun Facebooknya menyatakan, bahwa Pelaksanaan Pembatasan Sosial Berskala Besar telah dilaksanakan di empat provinsi serta 72 kabupaten dan kota, berdasarkan data yang ada efektifitasya di sejumlah daerah masih bervariasi, ada daerah yang mengalami penurunan kasus Positif Covid-19 secara gradual, konsisten, namun tidak drastis. Ada yang turun namun masih mengalami fluktuasi dan belum konsisten. Selain itu ada pula daerah yang sudah menerapkan Pembatasan Sosial Berskala Besar, tapi kasusnya tidak terpaut jauh dengan sebelum pelaksanaan Pembatasan Sosial Berskala Besar. ${ }^{28}$

Undang-undang dan peraturan di atas telah mengikuti prinsip umum pemerintahan yang baik sebagai negara dalam Pasal 10 Undang-Undang Indonesia Nomor 30 Tahun 2014 tentang Administrasi Pemerintahan, ${ }^{29}$ dengan tegas menyatakan bahwa Prinsip Tata Pemerintahan yang Baik mencakup prinsipprinsip berikut: 1. Prinsip kepastian hukum; 2. Prinsip pemanfaatan; 3. Prinsip Ketidakberpihakan; 4. Prinsip akurasi; 5. Prinsip penyalahgunaan wewenang; 6. Prinsip keterbukaan; 7. Prinsip kepentingan publik; 8. Prinsip pelayanan yang baik. (Zamroni, 2019) ${ }^{30}$

\section{- Kesimpulan} ditemukan:

Berdasarkan uraian pembahasan yang telah disampaikan, maka dapat

1. Cara Indonesia dalam membuat solusi penanganan wabah penyakit Covid19 melalui produk peraturan perundang-undangan, yakni:

a. Undang-Undang Nomor 6 Tahun 2018 tentang Kekarantinaan Kesehatan;

b. Keputusan Presiden Republik Indonesia Nomor 11 Tanun 2020 tentang Penetapan Kedaruratan Kesehatan Masyarakat Corona Virus Disease 2019 (Covid-19);

c. Peraturan Pemerintah Pengganti Undang-Undang Republik Indonesia Nomor 1 Tahun 2020 tentang Kebijakan keuangan Negara dan Stabilitas Sistem Keuangan untuk penangangan Pandemi Corona Virus Disease 2019 (Covid-19) dan/atau dalam Rangka Menghadapi Ancaman yang Membahayakan Perekonomian Nasional dan/atau Stabilitas Sistem Keuangan;

\footnotetext{
${ }^{28}$ https://www.facebook.com/Jokowi/, 13 Mei 2020, jam 22.33 Wib.

${ }^{29}$ Undang-Undang Indonesia Nomor 30 Tahun 2014 tentang Administrasi Pemerintahan

30 Zamroni, M. (2019). General Principles of Good Governance in Indonesia: What are
} The Legal Bases? Varia Justicia, 15(1), 1-8. https://doi.org/10.31603/variajusticia.v15i1.2464 
d. Peraturan Pemerintah Republik Indonesia Nomor 21 Tahun 2020 tentang Pembatasan Sosial Berskala Besar dalam Rangka Percepatan Penanganan Corona Virus Disease 2019 (Covid-19).

e. Peraturan Menteri Kesehatan Republik Indonesia Nomor 9 Tahun 2020 tentang Pedoman Pembatasan Sosial Berskala Besar dalam Rangka Percepatan Penanganan Corona Virus Disease 2019 (Covid);

f. Keputusan Menteri Kesehatan Republik Indonesia Nomor HK.01.07/Menkes/231/2020 tentang Tim Penetapan Pembatasan Sosial Berskala Besar dalam Rangka Percepatan Penanganan Corona Virus disease 2019 (Covid-19).

2. Implementasi pertama kali di Indonesia dilakukan oleh Gubernur Provinsi DKI Jakarta dengan mengajukan permohonan kepada Menteri Kesehatan Republik Indonesia untuk menetapkan wilayah Provinsi DKI Jakarta sebagai wilayah yang berstatus "Pembatasan Sosial Berskala Besar" dengan ditetapkannya: Keputusan Menteri Kesehatan Republik Indonesia Nomor HK.01.07/Menkes/239/2020 tentang Penetapan Pembatasan Sosial Berskala Besar di Wilayah Provinsi DKI Jakarta dalam Rangka Percepatan Penangan Corona Virus Disease 2019 (Covid-19), di Jakarta, pada tanggal 7 April 2020. ${ }^{31}$ Kemudian diikuti oleh Gubernur Jawa Barat, Gubernur Banten, dan Gubernur Jawa Timur.

3. Cara Indonesia menanggulangi Covid-19 dengan praturan perundangundangan ternyata memang tidak bisa menghentikan kasus Covid-19, namun mampu memperlambat.

\section{DAFTAR PUSTAKA}

\section{- Buku}

Ridwan H.R., Hukum Administrasi Negara (Edisi Revisi), PT. Rajagrafindo Perkasa, Depok, 2018.

Umi Chulsum, et.al. Kamus Besar Bahasa Indonesia, Kashiko Publisher, Surabaya, 2014.

\section{- $\quad$ Artikel Jurnal}

Andrea Remuzzi, "COVID-19 and Italy: What Next ", The Lancet, Volume 395, Issue 10231, P. 1225-1228, 11-17 April 2020.

M.Zamroni, General Principles of Good Governance in Indonesia: What are The Legal Bases? Varia Justicia, 15(1), 1-8. https://doi.org/10.31603/variajusticia.v15i1.2464, 15 Mei 2019.

Puja Mehta, et.al., "COVID-19: Consider Cytokine Storm Syndromes and Immunosupression", The Lancet, Volume 395, issue 10229, P1033-1034, March 28, 2020.

${ }^{31}$ Keputusan Menteri Kesehatan Republik Indonesia Nomor HK.01.07/Menkes/239/2020 tentang Penetapan Pembatasan Sosial Berskala Besar di Wilayah Provinsi DKI Jakarta dalam Rangka Percepatan Penangan Corona Virus Disease 2019 (Covid-19 
Qun Li, M.Med., et.al., (2020), Early Transmission Dynamics in Wuhan, China, of Novel Coronavirus-Infected Pneumonia, The New England journal of medicine, volume 382, issue 13, page 1199-1207, March 15, 2020.

Ying-Ying Zheng, et.al., "COVID-19 and The Cardiovasculer System", Nature Reviews Cardiology, 17, 259-260, 5 March 2020.

\section{- Internet}

https://www.who.int/indonesia/news/novel-coronavirus/qa-for-public, 20 April 2020.

https://www.kompas.com/tren/read/2020.04/06/171111665/2491-orang-positifcofid-19-di-indonesia-ini-rincian-kasus-di-32-provinsi?page=1, 25 April 2020.

https://www.kompas.com/covid-19, 13 Mei 2020.

https://www.facebook.com/Jokowi/, 13 Mei 2020.

\section{- $\quad$ Peraturan Perundang-undangan}

Keputusan Gubernur Jawa Timur Nomor 188/108/KPTS/013/2020 tentang Status Keadaan Darurat Bencana Wabah Penyakit Akibat Corona Virus Disease 2019 (Covid-19), ditetapkan di Surabaya pada 23 April 2020.

Keputusan Gubernur Jawa Timur Nomor 188/202/KPTS/013/2020 tentang Pemberlakuan Pembatasan Sosial Berskala Besar dalam Penanganan Corona Virus Disease 2019 (Covid-19) di Wilayah Kota Surabaya, Kabupaten Sidoarjo, dan Kebupaten Gresik.

Keputusan Gubernur Jawa Timur Nomor 188/219/KPTS/013/2020 tentang Perpanjangan Pemberlakuan Pembatasan Sosial Berskala Besar dalam Penanganan Corona Virus Disease 2019 (Covid-19) di Wilayah Kota Surabaya, Kabupaten Sidoarjo, dan Kabupaten Gresik, ditetapkan di Surabaya pada 9 Mei 2020.

Keputusan Menteri Kesehatan Republik Indonesia Nomor HK.01.07/Menkes/239/2020 tentang Penetapan Pembatasan Sosial Berskala Besar di Wilayah Provinsi DKI Jakarta dalam Rangka Percepatan Penangan Corona Virus Disease 2019 (Covid-19), ditetapkan di Jakarta pada 7 April 2020.

Keputusan Menteri Kesehatan Republik Indonesia Nomor HK.01.07/Menkes/248/2020 tentang Penetapan Pembatasan Sosial Berskala Besar di Wilayah Kabupaten Bogor, Kota Bogor, dan Kabupaten Bekasi, dan kota Bekasi, Provinsi Jawa Barat dalam Rangka Percepatan Penanganan Corona Virus Disease 2019 (Covid-19), ditetapkan di Jakarta pada 11 April 2020.

Keputusan Presiden Republik Indonesia Nomor 11 Tanun 2020 tentang Penetapan Kedaruratan Kesehatan Masyarakat Corona Virus Disease 2019 (Covid19), ditetapkan di Jakarta pada 31 Maret 2020.

Peraturan Pemerintah Republik Indonesia Nomor 21 Tahun 2020 tentang Pembatasan Sosial Berskala Besar dalam Rangka Percepatan Penanganan Corona Virus Disease 2019 (Covid-19), ditetapkan di Jakarta pada 31 Maret 2020, dicatat dalam Lembaran Negara Republik Indonesia Tahun 
2020 Nomor 91. Tambahan Lembaran Negara Republik Indonesia Tahun 20206487.

Peraturan Pemerintah Pengganti Undang-Undang Republik Indonesia Nomor 1 Tahun 2020 tentang Kebijakan keuangan Negara dan Stabilitas Sistem Keuangan untuk penangangan Pandemi Corona Virus Disease 2019 (Covid-19) dan/atau dalam Rangka Menghadapi Ancaman yang Membahayakan Perekonomian Nasional dan/atau Stabilitas Sistem Keuangan, ditetapkan di Jakarta pada 31 Maret 2020, dicatat dalam Lembaran Negara Republik Indonesia Tahun 2020 Nomor 87, dan Tambahan Lembaran Negara Republik Indonesia Nomor 6485.

Surat Edaran Gubernur Daerah Istimewa Aceh Nomor: 440/4820 tentang Cegah Virus Corona Melalui Ibadah, Perilaku Hidup Bersih dan Sehat, ditetapkan di Banda Aceh pada 12 Maret 2020.

Surat Edaran Gubernur DKI Jakarta Nomor: 2/SE/2020, tanggal 16 Maret 2020, tentang Penyesuaian Sistem Kerja Pegawai dalam Upaya Pencegahan Penyebaran Virus Corona atau Covid-19 di Lingkungan Pemerintah Provinsi DKI Jakarta, ditetapkan di Jakarta pada 16 Maret 2020.

Surat Edaran Gubernur Jawa Timur Nomor: 420/1780/101.1/2020, tanggal 15

Maret 2020, Perihal Peningkatan Kewaspadaan Corona Virus Disease 2019 (Covid-19), ditetapkan di Surabaya pada 15 Maret 2020.

Surat Edaran Gubernur Kalimantan Tengah Nomor: 443.1/25/2020 tentang Pengawasan dan Pencegahan Virus Covid-19 di Perbatasan dan Pesisir Wilayah Kalimantan Tengah, ditetapkan di Palangka Raya pada tanggal 19 Maret 2020.

Surat Edaran Gubernur Sumatera Utara Nomor: 440/2666/2020 tentang Peningkatan Kewaspadaan terhadap Resiko Penularan Infeksi Corona Virus Disease (Covid-19) di Sumatera Utara, ditetapkan di Medan pada 17 Maret 2020.

Undang-Undang Republik Indonesia Nomor 6 Tahun 2018 tentang Kekarantinaan Kesehatan, ditetapkan di Jakarta pada 7 Agustus 2018, dicatat dalam Lembaran Negara Republik Indonesia Tahun 2018 Nomor 128, dan Tambahan Lembaran Negara Nomor 6236.

Undang-Undang Indonesia Nomor 30 Tahun 2014 tentang Administrasi Pemerintahan, ditetapkan di Jakarta pada 17 Oktober 2014, dicatat dalam Lembaran Negara Republik Indonesia Tahun 2014 Nomor 292, dan Tambahan Lembaran Negara Nomor 5601. 